\title{
The collective vibration modes of hydrogen bonds as a gauge of water states in fruits and leaves
}

\author{
M. E. Kornienko, S. Y. Kutov
Physics Faculty, Kyiv Taras Shevchenko University
Vul. Volodymyrs'ka, 64, Kyiv, 01033, Ukraine \\ ${ }^{1}$ IWR, Heidelberg Universitat \\ Im Neuenheimer Feld 368, 69120 Heidelberg, Deutschland \\ E. mail: lns@univ.kiev.ua
}

\begin{abstract}
The new conception of the collective vibration modes (CVM) of the water medium is used to study water states in tissues (leaves and fruit). The CVM of the hydrogen bond $(H B)$ nets were studied by the methods of the Raman and infrared (IR) spectroscopy in the region of the low-frequency $L O$ and TO modes and high-frequency summary tones of these modes with fundamental vibrations. The frequency and intensity changes in the collective modes in comparison with distilled water are indicative of the HB nets ordered or disordered. It was found that in plant tissue the water can be both in disordered state as compared to distilled water and in more collectivized state. The existence of four different water states in leaves has been established.
\end{abstract}

Key words: Raman and JR spectroscopy, fruit juice, mezophyte and succulent leaves, water states, collective modes, $H B$-nets.

Introduction. In spite of simple structure of the water molecule, the study of the condensed state of water has faced more complicated problems as compared to the investigation of macromolecules which have more stable structure, less sensitive to external influence. At present there is a tendency to consider much more complicated clusters of hundreds water molecules. The formation of these stable structures is caused by the availability of the hydrogen bonds (HB) net. We believe that the model of global continuous HB-net, spreading through sizable volume, describes real nature of water.

(C) M. E. KORNIENKO, S. Y. KUTOVYI, O. V. PIDDUBETSKA, N. P. SMOLJAR, 2006
Earlier different methods were used to study the water states in the plant tissue, but all of them allow studying single-particle properties of water, whereas water as condensed medium has to be characterized by many-particle, collective properties. A new stage in the investigation of water in tissue was begun after we detected the collective nature of the vibration excitations in liquids [1-3]. The collective quasi-lattice modes are in essence the phonons in water medium. We believe that very perspective are the investigations of the valence band of the 0 - $\mathrm{H}$-bonds vibrations (3000-3700 $\mathrm{cnf}^{\mathrm{l}}$ ) and collective TO, LO-modes of the HB-net revealed in the low frequency range of 50-350 $\mathrm{c} \Pi \Gamma^{1}$ of Raman spectra. The existence of that was supposed theoretically and shown experimentally by Kornienko et al. [1-8] using, in particular, the second derivative spectra: $\mathrm{v}_{\mathrm{TO}}-220 \mathrm{~cm}^{\prime 1}, \mathrm{~V}_{\mathrm{LO}}==288 \mathrm{~cm}^{\prime \prime}$ (at $0{ }^{\circ} \mathrm{C}$ ). The shoulder 

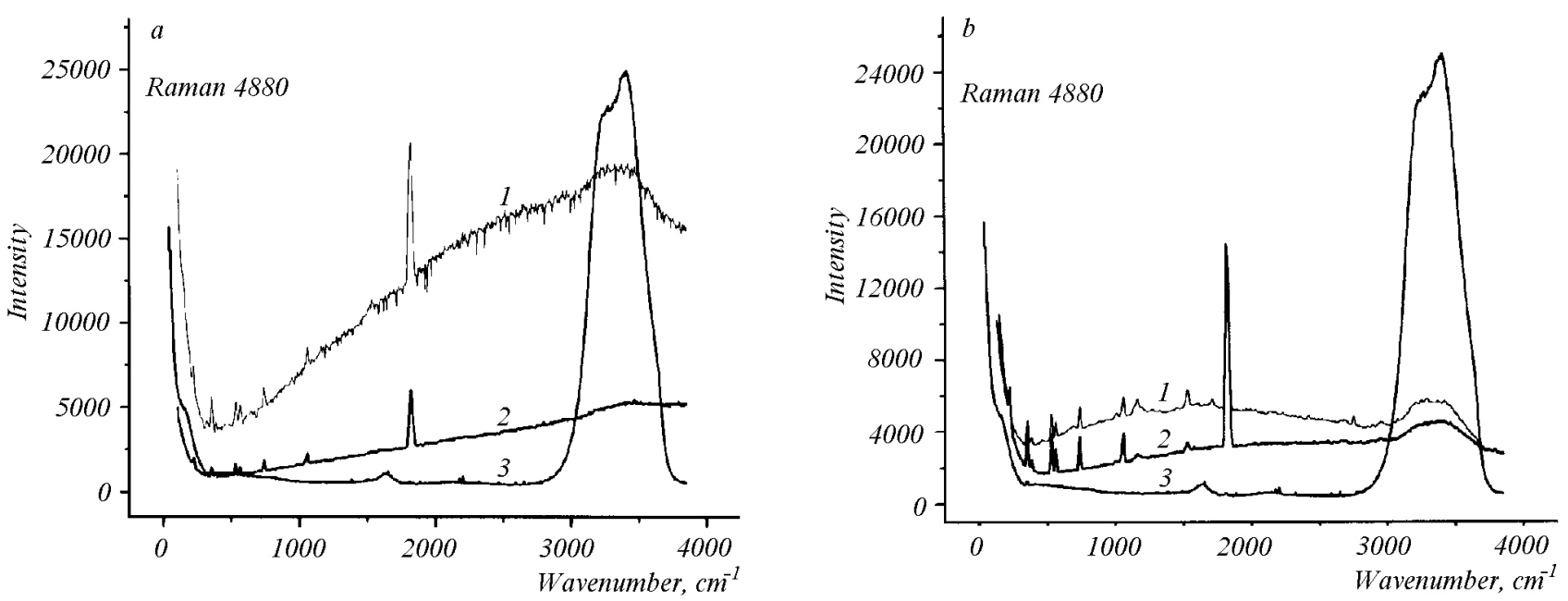

Fig. 1. Raman spectra of the apple (a) and lemon (b) juice: fresh (/) and settled (2), and distilled water (j)

near $120 \mathrm{~cm}^{\text {"1 }}$ was attributed to the LA-mode. The criteria of the relative increase in the force of HB-net are the increase in frequency and total intensity of LO, TO modes and the decrease in valence band frequency. The existence of low-frequency collective modes and LO-TO-splitting is indicative of the quasi-crystal structure of water.

The purpose was to study the different vibration modes in Raman spectra of bioactive water and to compare that with spectra of controlled distilled water. As a model of bioactive water some fruit (apple, orange, lemon), vegetable (cucumber, onion) juices, and birch juice were taken. It was caused by small concentrations of impurities that did not complicate the observation of water vibration bands.

The spectra of fresh, settled and commercial packed juices were obtained in the frequency range of 50-4000 $\mathrm{cm}^{\prime 1}$. The behaviour of the Raighley wing (up to $140 \mathrm{~cm}^{\prime 1}$ ), low-frequency collective modes $\left(100-300 \mathrm{~cm}^{\prime \prime}\right)$, the form and intensity of the valence band $\left(3000-3700 \mathrm{~cm}^{\prime \prime}\right)$ were studied. Also the time fluctuations of some new narrow lines and the background were investigated. The method of the infrared (IR) spectroscopy was used for investigations of the collective modes in the region of the overtones and compound tones of the fundamental and quasi-lattice modes of the HB-net of highly scattered leaves of succulent plants (kalanchoe) and mezophyte leaves (lobacco, ricinus),

Materials and Methods. The Raman scattering. The Raman spectra were obtained in conventional $90^{\circ}$-geometry using a double-grating monochromator DFS-24 and a photon counting electronics. The 4880 and 5145 A lines of Ar-laser were used for excitation.
The general view of Raman spectra of fruit juices is shown in Fig. 1 (apple and lemon juices). One can see that in comparison with distilled water the spectra of juices are characterized by the wide-band background with maximums at frequencies specific for each kind of juice. As compared to water, the noise track is much wider at the same cattering intensity, besides with the intensity increase up to the background maximum, its relative magnitude also increases (typically it must be contrary, $\delta I / I \sim 1 / \sqrt{I}$ ).

The Raighley wing intensity also increased appreciably, more for fresh, less for hardened and manufactured juices, but the valence band intensity (relative and total) significantly decreased. New narrow lines, which are not caused by organic substances, appeared [8,9].

The collective low frequency modes. The low-frequency modes were investigated directly in comparatively homogenous fruit and vegetable juices in the frequency range of 50-350 $\mathrm{cm}^{\prime \prime}$. As it turned out, the TO-mode, which is available in distilled water at $180 \mathrm{~cm}^{\prime \prime}$ as Raighley's line shoulder, is absent in juice spectra. The LO-mode frequency appreciably decreased in juices $-\mathrm{e}$. g., in lemon from 276 to $221 \mathrm{~cm}^{\prime \prime}$. This frequency $(-220$ $\left.\mathrm{cm}^{\prime \prime}\right)$ is characteristic of all investigated juices $[8,9]$. The power of HB-net can be estimated from the change in frequency and intensity of the TO-mode. The spectra of the fresh birch juice are presented as an example in Fig. 2. It is seen that the low frequency modes of the HB-net are considerably decreased. As a whole, since the collective optical modes in juices, in particular TO, are significantly damaged in comparison with distilled water, it may indicate the absence of substancial $(\sim 0.5 \mathrm{~mm})$ areas of structural order 
The frequency, halfwidth and the total intensity of the water valence band in juices

\begin{tabular}{|c|c|c|c|c|c|}
\hline Parameter & $\mathrm{H}_{2} \mathrm{O}$ & Orange & Lemon & Apple & Cucumber \\
\hline \multicolumn{6}{|c|}{ fresh } \\
\hline$v, \mathrm{~cm}^{-1}$ & 3405 & - & 3396 & 3396 & 3396 \\
\hline$\delta v, \mathrm{~cm}^{-1}$ & 445 & - & 467 & 531 & 479 \\
\hline$I$ & $100 \%$ & $\sim 0$ & $13.8 \%$ & $21.5 \%$ & $8.9 \%$ \\
\hline \multicolumn{6}{|c|}{ Settled } \\
\hline $\mathrm{n}, \mathrm{cm}-1$ & 3405 & 3307 & 3889 & 3426 & 3396 \\
\hline $\mathrm{dn}, \mathrm{cm}-1$ & 445 & 516 & 463 & 494 & 489 \\
\hline$I$ & $100 \%$ & $4.1 \%$ & $9.2 \%$ & $3.75 \%$ & $19.2 \%$ \\
\hline
\end{tabular}

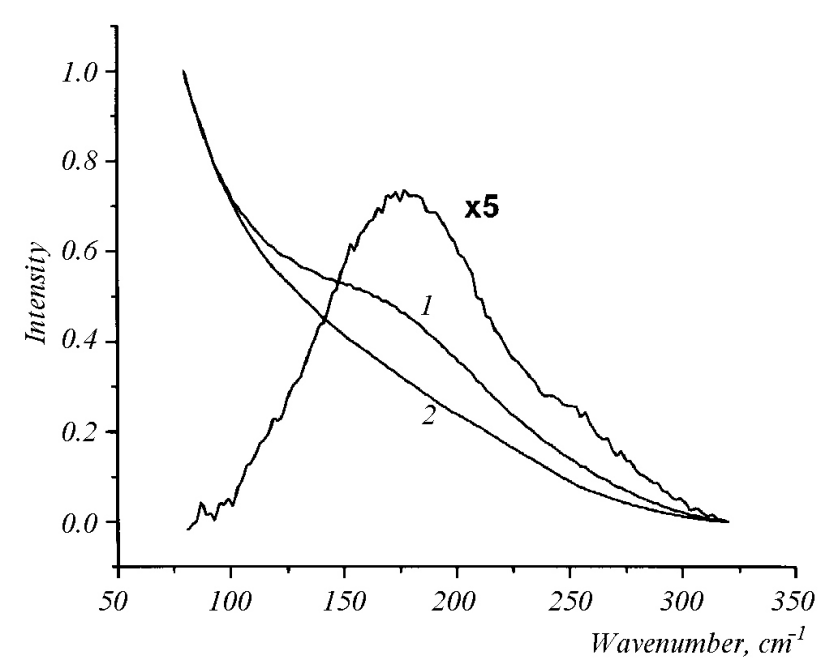

Fig. 2. The low frequency Raman spectra of water (/), birch juice (2) and the differential spectrum

(clusters) in juices, which are available in distilled water, i. e. the water in fruits is a more disordered system.

The Raighley wing. It is believed that the Raighley wing is an exhibition of a rotational spectrum. The existence of a quasi-crystal rest of the

lattice and vibration modes of it is assumed, but the division on acoustical and optical modes was not carried out. As it was found, in juices the intensity of the far Raighley wing is considerably higher in comparison with distilled water that can be explained by decreased viscosity of medium. It was confirmed experimentally for the birch juice. The viscosity decrease can be caused by the HB-net slackening; it correlates with considerable quenching of the TO-modes. The highest intensity of the Raighley wing was observed in lemon and apple juices, a little less in orange and cucumber [8]. In settled juices in comparison with fresh ones the Raighley wing intensity decreases, almost to the distilled water level in hardened apple juice. It is indicative of the viscosity increase caused by the strengthening of the HB-net with the time. It is considered that the

decreasing of the Raighley wing intensity is particularly caused by an exhibition of acoustical modes in Raman spectra.

The valence band. The scattering cross-section is appreciably larger in liquids than in gases. It is caused by the increase in acting field and intermolecular interactions (IMI). At the investigation of organic liquids with $\mathrm{HB}$ of the C-H (C-D) type [10] it was shown that the scattering cross-section is $3-4$ times larger. The contribution of IMI in the cross-section provides the additional -1.5-fold increase of the scattering intensity for valence vibrations of the $\mathrm{C}-\mathrm{H}$-bonds that is caused by the formation of the weak HB. For liquid with strong HB - water one would expect greater increase of the scattering intensity. Hence, the HB strengthening must be followed by the increase of total intensity of the $\mathrm{O}-\mathrm{H}$-bonds valence vibrations.

It was observed that the total intensity of the valence band of the $\mathrm{O}-\mathrm{H}$-bonds vibrations decreases abnormally (10-20 times) in juices in comparison with distilled water (see Table). In fresh lemon juice the total intensity of the valence band came to $14 \%$ only, in orange the intensity decreased up to the underground level [8 ]. Using the second derivative spectra the frequency shift of the valence band components was analysed. It turned out that the valence band components were broadened and its frequencies decreased. The low-frequency components of about 3200 


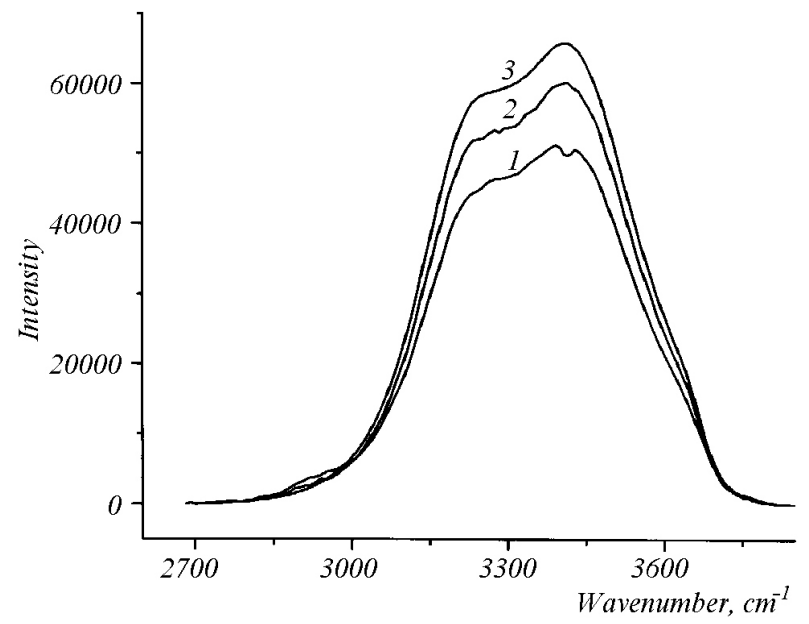

Fig. 3. The Raman spectra of the valence band of the O-H-bonds in the fresh birch juice (7), birch juice after 24 hours storage (2) and distilled water (3)

$\mathrm{cm}^{\sim}$ decreased in intensity that can also indicate the HB-net weakening.

The mechanism of the decrease of total valence band intensity can be caused by changes in charge transferring processes, in particular, changes in electron system at HB forming. The intensity decrease in the valence band is connected with the decrease in the derivative of the electron polarization in normal coordinates $d a / d Q$. This is evidence of the weakening of water collective properties and may bring the decrease in the water structural ordered area substantial decrease in total intensity indicates that on single-particle contribution is not basic (otherwise, such sharp decrease of intensity would not be possible), thus dominating is the contribution of collective effects. From changes in total intensity (taking into account less transparency of juices) it can be concluded that the areas of the strong HB are - 5 times less as compared to distilled water and comprise $\sim 60 / * \mathrm{~m}$. This effect is doubtless, because the intensity decrease was even more appreciable in more transparent hardened and transparent conserved juices. The changes of the valence band intensity in the birch juice are shown as an example in Fig. 3. With the time the valence band intensity increased in the birch juice and became more like to water one.

The time fluctuations. The background and new lines. It is known that all functions of the organism are characterized by the fluctuation dynamics. The violations of the functional condition are followed by changing in low-frequency stochastic processes. With the time the regulation systems became less flexible. As a result the total fluctuation amplitude decreases, the high-frequency components of the fluctuation spectra decrease too. That is, the fluctua- tion processes may be the sources of the advanced, preventive information about regulation systems [111. We assume that the amplitude of fluctuations is an important characteristic of bioactive water. If fluctuations are larger the system is more flexible, more adaptable to different processes in organism. The fluctuations can be associated with the rearrangement of the supramolecular water structure.

It was found that the fluctuation level is significantly larger in all investigated bioactive liquids (juices) than in the distilled water. The amplitude of fluctuations increases at the beginning with the frequency shift and then decreases, i. e. it is the largest in the maximum of background wide-band [\%]. We consider that the background wide-band of several thousands $\mathrm{cm}^{\text {"1 }}$ is caused by the processes in electronic (not ionic) system which plays an important role in the formation of $\mathrm{HB}$, therefore the correlation between maximal dispersion of fluctuations and maximum of the background seems to be reasonable. In settled and packed juices fluctuations are considerably less which, in our opinion, may be an evidence of their decreased bioactivity. Both the increase in the wide-band background intensity and the fluctuations of the scattering intensity are indicative of the water disorder in juices.

Some new narrow lines with peculiar behaviour were observed in Raman spectra of juices. These lines are not caused by organic substances (i. e. line $2950 \mathrm{~cm}^{\prime 1}$ of the $\mathrm{C}-\mathrm{H}$-bonds vibrations), therefore, this points to the water states changes. A comparison of the fresh and settled juices shows that certain lines increase with time, other lines decrease. In sub-tractive spectra they are observed as "absorption" and "emission" lines, respectively. These lines are connected with certain unknown properties of water structure. The presence of these lines can be a criterion of the water bioactivity. The time fluctuations of these lines were studied.

The time fluctuation behaviour of the $1820 \mathrm{~cm}^{\prime 1}$ line and the background close to the maximum at $2142 \mathrm{~cm}^{\prime \prime}$ in orange juice are presented as an example in Fig. 4. Besides, short-time (10-15 s) abrupt decrease in the intensity of these lines was revealed. It indicates the change in electron states and consequently in the structure of the HB-net (clusters dynamics) in direction to the distilled water structure. It should be noted that from this viewpoint the ice water is more active than the distilled one.

The I Я-absorption, The IR-spectra were obtained using IR-spectrometers HP 8453 and UV-vis-NIR Spectrometer SCAN 500, The infrared absorption spectroscopy was used for investigation of the collective modes in the region of the overtones and compound tones of the fundamental and quasi-lattice modes of the HB-net of highly scattered leaves of succulent plants (kalanchoe) and 

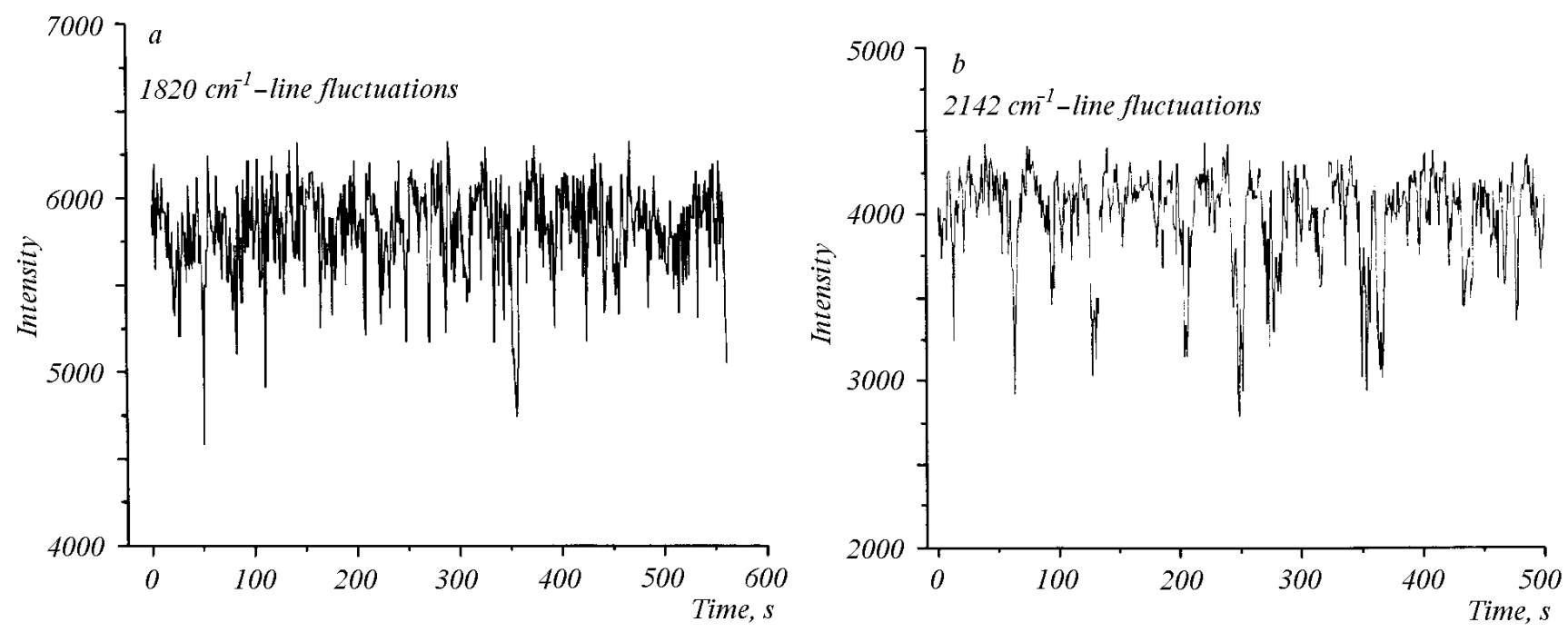

Fig. 4. Time fluctuations of the $1820 \mathrm{~cm}^{-1}$-line intensity (a) $2142 \mathrm{~cm}^{-1}$-background intensity (b) in fresh orange juice
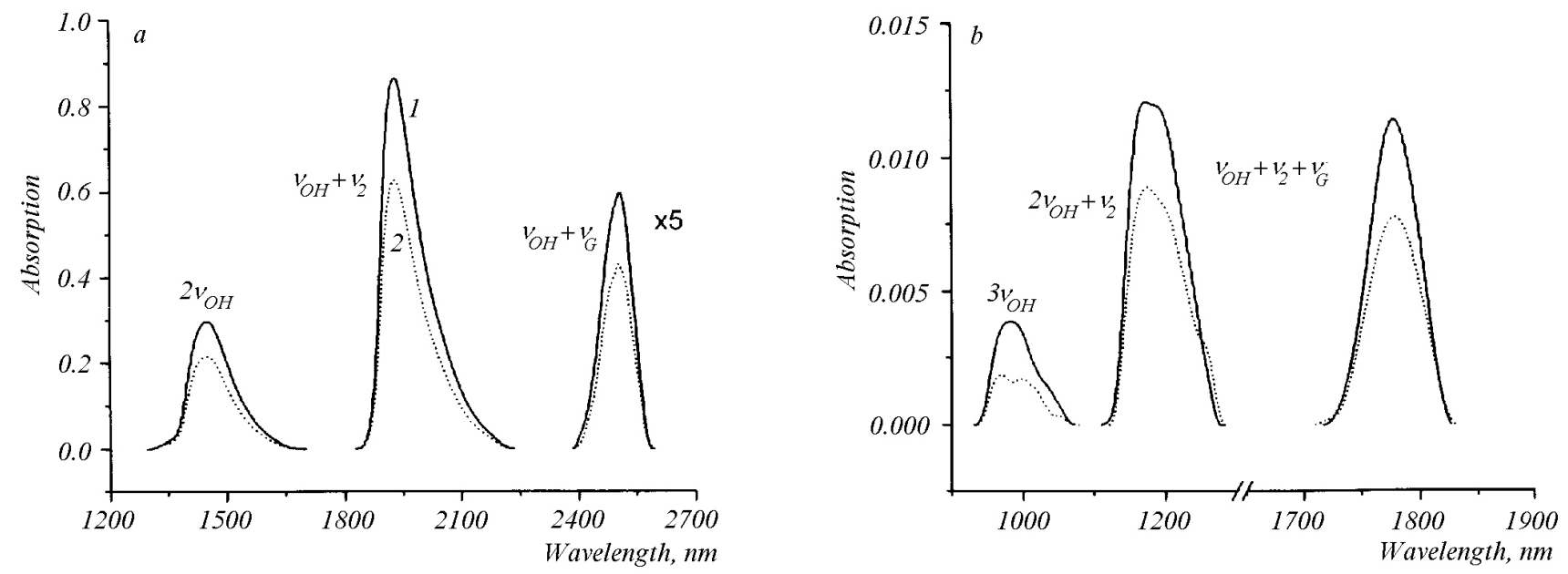

Fig. 5. The second-order (a) and the third-order modes (b) in IR-absorption spectra or the tooacco ana ricinus leaves: ; $1-$ tobacco; $2-$ ricinus

mezophyte leaves (tobacco, ricinus). The compound tones are important for the study of water states in leaves because of strong absorption of water in the region of fundamental modes $\mathrm{V}_{\mathrm{OH}}$ and $v_{2}$.

The overtones $2 \mathrm{v}_{\mathrm{OH}}(1450 \mathrm{~nm}), 3 \mathrm{v}_{\mathrm{OH}}(970 \mathrm{~nm})$ and compound tones $\mathrm{V}_{\mathrm{OH}}+\mathrm{v}_{0}(2505 \mathrm{~nm}), \mathrm{v}_{\mathrm{OH}}+\mathrm{v}_{2}(-1930 \mathrm{~nm})$, $\mathrm{v}_{\mathrm{OH}}-{ }{ }^{2} \mathrm{r}_{2}+\mathrm{v}_{\mathrm{G}}(1778 \mathrm{~nm}), 3 \mathrm{v}_{\mathrm{OH}}+\mathrm{v}_{2}(850 \mathrm{~nm})$ with the valence mode $\mathrm{V}_{\mathrm{OH}}$, deformation mode $\mathrm{v}_{2}$ and the lattice mode $\mathrm{v}_{0}$ were studied [9]. The $\mathrm{V}_{\mathrm{OH}}+\mathrm{v}_{\mathrm{c}}$ mode is rather intensive and amounts to about 40 percents of the $2 \mathrm{v}_{\mathrm{OH}}$ overtone intensity (Fig. 5, a). The $\mathrm{v}_{\mathrm{OH}} 4 \mathrm{v}_{2}+\mathrm{v}_{\mathrm{ci}}$ mode is the most intensive among the third-order modes. In distilled water the intensity of this mode is 2.3 times greater than the $3 \mathrm{v}_{\mathrm{OH}}$ overtone intensity, in leaves of tobacco and ricinus this mode is 2.95 and 4.17 times greater, correspondingly (Fig. 5, b). It points to the importance of the lattice modes of the HB-net in leaf water. The strengthening of the collective properties of water in leaves is evidenced by the increase in $\mathrm{V}_{\mathrm{OH}}+v_{2}+$ $\mathrm{v}_{\mathrm{c}}$ mode intensity and the frequency shift of this mode relatively to the $\mathrm{v}_{\mathrm{OH}}+V_{G}$ mode. The shift increases from 432 $\mathrm{cm}^{\prime \prime}$ to $447 \mathrm{~cm}^{\prime \prime}$ passing from distilled water to water in leaves.

Rather an interesting manifestation of the collective properties of water in leaves is the considerable decrease in the IR-absorption in the region of the intense vibration modes. In particular, in the first overtone region specific for thick water saturated leaves of succulent plants (kalanchoe) the intensity is much less than for the thinner mezophyte leaves (Fig. 6). It is shown also that the water in mesophyte and succulent veins can be more coherent as 


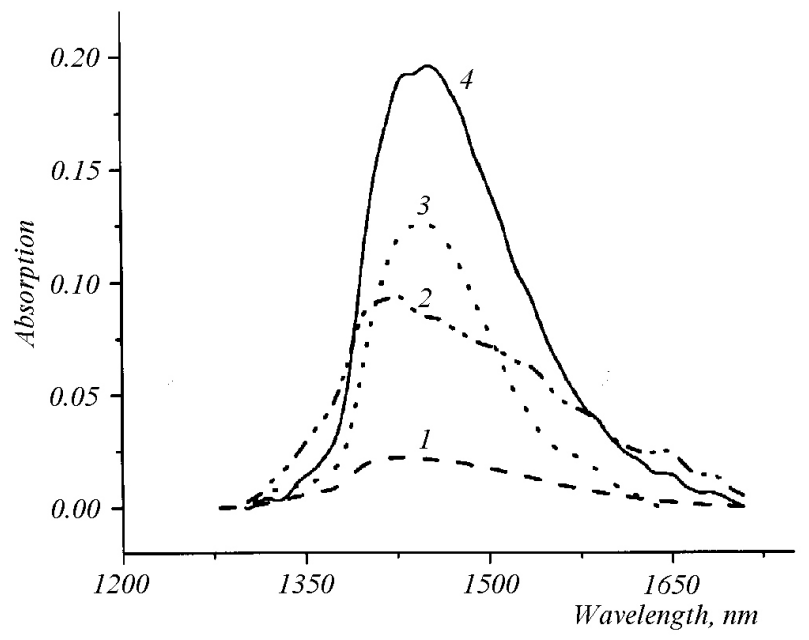

Fig. 6. The absorption bands of the Kalanhoe blossfeldiana (/); Kalanhoe briophullum (2); ricinus (3) and tobacco (4)

compared to pure water and it leads to considerable decrease in the IR irradiation in the intensive water bands.

The bulk water content in leaves can be characterized by the strongest bands $2 \mathrm{v}_{\mathrm{OH}}, \mathrm{V}_{\mathrm{OH}}+\mathrm{v}_{2}$. Water in plants can be subdivided into free and bound water in different locations: transported water in intercellular spaces and conducting systems, stored water of vacuoles, hydratation water in proteins, enzymes, colloids, and shells of membranes.

In general, the existence of four different water states in leaves was found. They can be identified by the parameters of bands $3 \mathrm{v}_{\mathrm{OH}}, 3 \mathrm{v}_{\mathrm{OH}}+\mathrm{v}_{2}$. [12,13]. The first water state is similar to distilled water, for which the band $3 \mathrm{v}_{\mathrm{OH}}$ has the greatest intensity in the spectral area of 700-1100 $\mathrm{nm}$. The second water state is described by abnormal intensity increase in the band $3 \mathrm{v}_{\mathrm{OH}}+\mathrm{v}_{2}$. The first water state is typical for succulent leaves with large water stores inside. The mesophytic leaves contain both water states. The third water state dominates in plant juices and cut leaf vein and can be characterized by four absorption bands $720,795,880$, $970 \mathrm{~nm}$ with similar intensities.

The displacement of the band of the $3 \mathrm{v}_{\mathrm{OH}}$-overtone to $1000-1090 \mathrm{~nm}$ was observed in thin films of leaves surface and cuts of their tissues. This corresponds to the strongly bound water in the hydrated shells of macromolecules structure. It is the fourth state.

Conclusion. The low-frequency collective modes are significantly suppressed and modified in juices their intensity is considerably less in comparison with distilled water. It indicates a high degree of disorder in the HB-nets; water in fruits is a more disordered system in comparison with distilled water. This is confirmed by the increase in the far Raighley wing intensity, considerable decrease in the valence band intensity, and the intensity increase in the wide-band background too. A high degree of fluctuations is characteristic of very fresh juices. In settled juices fluctuations are considerably smaller. It can indicate degression of water bioactivity. For some juices single backswings are observed. The narrow lines $\left(221 \mathrm{~cm}^{\prime 1}, 1820 \mathrm{~cm}^{\prime \prime}\right.$ etc.), which are not caused by dissolved substances, and the intensive wide-band background appeared. In settled and conserved juices the intensity of narrow lines, background spectral distribution and dispersion of fluctuations are noticeably different from the fresh ones. This can be used for attesting bioactivity and the quality control.

The existence of four different water states in leaves was found. They can be described by the parameters (the band intensity and frequency shift) of the overtones and compound tones in IR-absorption spectra.

As a whole, the water in plant tissue can be both in highly disordered state in comparison with distilled water and in more ordered appreciably collectivized coherent state.

\section{М. Є. Корнієнко, С. Ю. Кутовий, О. В. Шддубецька, Н. П. Смоляр}

Колективні коливальш моди стси водневих зв'язкш як показник сташв води в рослинних соках та листках

\section{Резюме}

Концепцию колективних коливальних мод (ККМ) водних сере-довищ, застосовано для вивчення сташв води у тканинах рослин (листки $i$ плоди). Методами рамашвсько! спектро-скопП та Інфрачервоного (14) поглинання досл1джено ККМ сітки водневих зв'язків в области низькочастотних TO i LO мод, високочастотних сумарних тошв иих мод з фундамен-тальними коливаннями. Знайдено, шр в листках і соках рослин вода може кнувати у мени зв'язаному стат поршняно $з$ дистильованою $і$ в колективБзовашшому стаж. В листках рослин нами виявлено 1снування чотирьох різних структурних сташв води, якг можно ідентифікувати за параметрами смуе (ттенсившсть $i$ частотний зсув) обертошв та складних тапіа у спектрах IЧ-поглинання.

Ключові слова: Коливальна спектроскотя, сшка водневих зв'яяків, стани води., колективш моди.

\section{Н. Е. Корниенко, С. Ю. Кутовой, Е. В. Поддубецкая, Я. Я. Смоляр}

Коллективные колебательные моды сетки водородных связей как указатель состояния воды в листьях и соках растений.

\section{Резюме}

Концепция коллективных колебательных мод (ККМ) водных сред использована для изучения состояний воды в тканях растений (листья и плоды). Методами романовской спектроскопии и инфракрасного (ПК.) поглощения исследованы ККМ сетки водородных связей в области низкочастотных TO и LO мод, высокочастотных суммарных тонов этих мод с фундаментальными колебаниями. Обнаружено, что в листьях и соках растений вода может находиться в менее связанном состоянии сравнительно с дистиллированной и в более коллективизированном состоянии. В листьях растений выявлено существование че- 
тырех различных структурных состояний воды, которые можна идентифицировать па параметрам полос (интенсивность и частотный сдвиг) обертонов и составных танов в спектрах ИК-поглощения.

Ключевые слова: Колебательная спектроскопия, сеткаводородных связей, состояния воды, коллективные моды.

\section{REFERENCES}

1. Kornienko M. E. LO-TO splitting and collective vibration excitations in liquids and amorphous medium // Physics of liquid matter.-Kiev, 1989.-Issue 17,-P. 93.

2. Kornienko M. E. Low frequency collective modes of the HB-net of water // Ukr. Fiz. J. -2002. -47. -P. 361-364.

3. Kornienko M. E. Observation of the LO-TO splitting in Raman spectra of liquids // Ukr. Fiz. J. -2001. -46. -P. 546-552.

4. Kornienko M. E. Low-frequency collective vibrational modes of water // Proc. Int. Bunsen Discus. Meet. "Metastable Water": Abstracts. - Schloss Nordkirchen, 1999. -P. 42.

5. Kornienko M. E. Low-frequency collective vibrational modes of hydrogen bonds net as the key to interpretation of the vibration sectra of water // Proc. Int. Conf. "Problems of Optics": Abstracts.-Kyiv, 1999.-P. 17.

6. Kornienko M. E. Transverse-longitudinal split up of acoustic and optical modes of hydrogen bonds system of water // Proc. Int. Conf. of Spectral Line Shapes (ICSLS-XV, Physikalisch-Technische Bundesanstalt): Abstracts.-Berlin, 2000.-P. 107.
7. Kornienko M. E., Loutsenko A. V. Researching collective low-frequency modes as a new quantitative method of studying liquid structure // Proc. Int. Conf. "Physics of Liquid Matter: Modern Problems": Abstracts.-Kyiv, 2001.-P. 151.

8. Kornienko M. E., Kutovyi S. Yu., Piddubetska O. V. The peculiarities of Raman spectra of bioactive water // Proc. Int. Conf. "Physics of Liquid Matter: Modern Problems": Abstracts.-Kyiv, 2001,-P. 152.

9. Kornienko M. E., Kutovyi S. Yu., Piddubetska O. V., Smoljar N. P. The collective vibration modes of hydrogen bonds as biometer of the states of water in vegetal fruits and leaves // Proc. Int. Conf. "Botanikertagung-2002": Abstracts.-Freiburg, 2002.-P. 395.

10. Raman spectroscopy of Gases and Liquids / Ed. A. Veber.Amsterdam: Springer, 1979.-376 p.

11. Uritskiy V. M., Muzatevskaya N. I. Fractal structures and biology processes // Biomed. Inform.-S-Petersburg.: SPI-IRAN, 1995.-P. 84-129.

12. Kornienko M. E., Smoljar N. P., Jahne B., Schurr U. Different water states in plant leaves. Image spectroscopy of leaves water // Proc. Int. Conf. "Botanikertagung-2002": Abstracts.-Freiburg, 2002.-P. 239.

13. Kornienko M. E., Smoljar N. P., Jahne B., Schurr V. Image spectroscopy and spectral determination of the water contents in plant leaves // Proc. Int. Conf. "Botanikertagung-2002": Abstracts.-Freiburg, 2002.-P. 239-240.

УДК 535.58

Надшшла до редакцп 19.04.04 